\title{
The interleukin-1 cluster, dyslipidaemia and risk of myocardial infarction
}

\author{
Bernard Keavney
}

\begin{abstract}
Coronary heart disease (CHD) is among the most serious worldwide health problems. Recent genetic studies have robustly identified a number of polymorphic loci throughout the genome that are associated with disease risk but it is certain that more remain to be discovered. It is well established that inflammation plays a key role in the pathophysiology of CHD. Determining whether or not polymorphisms in genes involved in the inflammatory cascade affect the risk of $\mathrm{CHD}$ is of considerable interest with respect to understanding the direction of the causal arrow between increased expression of inflammatory genes and CHD. Establishing an association between the variation in inflammatory genes and CHD would provide conceptual support for the use of appropriately specific antiinflammatory agents in CHD prevention and, potentially, suggest new therapeutic targets. This month in BMCMedicine, Benjamin Brown and colleagues adopt a family-based case-control association study design to address this question. In a large number of CHD cases and healthy sibling controls genotyped for 51 mainly coding single nucleotide polymorphisms (SNPS), they find evidence for the association of a common haplotype at the Interleukin-1 (IL-1) cluster with CHD which appears to be stronger in younger cases without hypercholesterolaemia. They also find suggestive evidence for an association between this same haplotype and hypercholesterolaemia. If replicated in other cohorts, these results could be of substantial importance in advancing the understanding of the way in which inflammatory genes affect coronary heart disease risk.

See the associated research paper by Brown et al: http://www.biomedcentral.com/1741-7015/8/5
\end{abstract}

\section{Commentary}

This month in BMC Medicine, Benjamin Brown and colleagues present a large genetic study which specifically addresses the effect of polymorphisms in genes involved in the inflammatory process on the risk of coronary heart disease (CHD) [1]. In this commentary, I discuss recent results in the coronary disease genetics literature pertinent to the findings of Brown et al., examine the difficulties inherent in assigning causal roles to the measurements of particular plasma biomarkers of inflammation in CHD and discuss the approach sometimes termed 'Mendelian randomization', which has in recent years been increasingly used to address this issue.

Numerous epidemiological studies and large meta-analyses have convincingly shown evidence for the association between higher plasma levels of a number of the inflammatory proteins coded for by inflammatory genes (most extensively, C-reactive protein [CRP] but also some members of

* Correspondence: b.d.keavney@newcastle.ac.uk

${ }^{1}$ BHF Professor of Cardiology, Institute of Human Genetics, Newcastle

University, Newcastle, UK the interleukin family) and CHD risk. However, the associations are less strong than those observed for 'classical' risk factors such as low-density lipoprotein-cholesterol, and the magnitude of the associations observed has tended to be quite sensitive to the degree of adjustment for potential confounding factors that has been made [2-4]. This raises the possibility that the association between such inflammatory proteins and CHD risk is largely, or possibly entirely, due to confounding or 'reverse causality' [5]. Reverse causal bias can arise in situations when subclinical manifestations of a disease process which starts early in life (such as CHD) are already sufficient to cause elevations in candidate biomarkers at the time that a prospective cohort is ascertained, such that an association is observed between baseline levels of the biomarker and subsequent clinical manifestations of the disease process. With respect to CHD and biomarkers of inflammation, higher levels of CRP have been shown even among children who have higher levels of 'classical' risk factors for CHD, such as obesity [6-8]. Of course, if the addition of plasma levels of particular factors to existing risk algorithms significantly improves their predictive util- 
ity, this would constitute a clinical advance, even if the association could not be proved to be causal. However, a strong presumption of causality is necessary before a particular gene product could be pursued as a potential therapeutic target. For a number of plausible candidate inflammatory genes, this remains an open question. Establishing robust associations between single nucleotide polymorphisms (SNPs) in such genes which affect the plasma levels of the gene product and CHD would constitute strong evidence in favour of a causal involvement in disease, an approach sometimes termed 'Mendelian randomization' [9].

Genomewide association studies (GWAS) of CHD, in which the genotypes at hundreds of thousands of common genetic variants (SNPs) throughout the human genome are compared in thousands of CHD cases and a similar number of controls have, in recent years, had a substantial degree of success in identifying loci robustly associated with CHD [10-14]. Thus far, around a dozen loci have been detected. Many have associations with plasma lipoprotein levels but some, including the effect that has consistently been identified as the strongest (on chromosome 9p21), are uncorrelated with any of the 'classical' risk factors for CHD. It is perhaps noteworthy that no GWAS has convincingly implicated any of the inflammatory genes that are the subject of Brown et al.'s analyses. However, one limitation of the GWAS approach is that the heavy penalty for multiple testing that must be imposed for assessing genotypes at very many loci to some extent limits the power of the approach to detect weak effects. Meta-analysis of GWAS datasets has been carried out in order to attempt to address this issue [15-17]. In the meta-analyses conducted so far, which have included up to 25,000 cases, no strong associations with the inflammatory genes studied by Brown et al. have been discovered. However, due to the play of chance, it would not be expected that even such studies would detect all the common variants affecting CHD risk. Moreover, GWAS analyses have, thus far, been confined to examining typed variants one-by-one rather than in ordered series of genotypes along chromosomal segments (haplotypes) during the initial screening stage involving all SNPs. Therefore, effects on risk conferred, not by genotype at one SNP but by the interaction of multiple loci on a haplotype, could have been missed. There is precedent for important effects of this type. For example, the epsilon-2/epsilon-3/epsilon-4 isoform polymorphism in the Apolipoprotein $\mathrm{E}$ gene is defined by the genotype at two nonsynonymous SNPs at codons 112 and 158 of the protein. The ApoE isoform polymorphism has been shown in large studies to be strongly associated with CHD risk (with a per-allele risk ratio of around 1.3) [18], and yet SNP-by-SNP analysis in the GWAS studies conducted thus far has consistently failed to identify ApoE as a strong risk gene. Thus, even in the GWAS era, there remains a place for more focused exami- nations of candidate genes in large cohorts, particularly if haplotype-specific effects are investigated.

Brown et al. examined the relationship between 51 common genetic polymorphisms in 35 genes involved in inflammation and the risk of CHD, in a large collection of 2699 siblings from 891 families of whom 1154 had CHD. They utilized statistical tests which took account of the 'overmatched' nature of family as opposed to unrelated controls and adjusted, where possible, for the effects of 'classical' CHD risk factors. In unadjusted analyses, they found evidence for an association between CHD and a long-range three-locus haplotype spanning $52 \mathrm{~Kb}$ of the IL-1 gene cluster. The haplotype is common (frequency 0.41 ), so even the relatively small effect on CHD risk that was found (odds ratio [OR] per copy $1.21 ; 95 \% \mathrm{CI}$ [confidence interval] $1.04-1.40 ; P=0.006$ ) could translate into a fairly substantial effect at the population level. However, after full adjustment for classical risk factors, the result was no longer significant. This prompted Brown et al. to test whether the association between the IL-1 cluster haplotype and CHD could be mediated through a classical risk factor. Intriguingly, a borderline significant association was observed between hypercholesterolemia and the IL-1 risk haplotype (OR 1.15; 95\% CI 1.03-1.29; $P=0.01$ ). Brown et al. acknowledge the potential for the association with hypercholesterolaemia to be confounded due to the strong correlation between MI and treatment with statin drugs, which was one of the criteria they used to define hypercholesterolaemia. Nevertheless, the suggestion that the IL-1 haplotype adversely affects plasma lipids is one that merits further study, possibly in a quantitative fashion in cohorts without the high level of statin exposure present in the study of Brown et al. It is perhaps noteworthy that joint analyses of GWAS data from up to 40,000 individuals have, not, thus far, shown any effect of the IL-1 locus on plasma lipids [19-22], although, in general, haplotype analyses, as noted above, have not featured in the screening stage of such investigations. Genetic polymorphisms identified so far that affect plasma lipid concentrations (with the exception of the effect of polymorphism at the apo(a) locus on plasma levels of lipoprotein(a), which is substantial), account for only a small fraction of the calculated heritability of the lipid traits investigated. Indeed, this same pattern has been observed for other quantitative phentotypes, such as height, and all complex diseases so far studied using GWAS. The majority of the effort to find what has been termed the 'missing heritability' of complex traits is presently focused on the investigation of genetic variation not captured in GWAS studies, such as rare variants using ultrahigh throughput sequencing and complex copy number variants. However, the existence of long-range haplotypespecific effects that can be detected by combinations of SNPs, such as that illustrated by Brown and colleagues, is a potential explanation for a proportion of the missing herita- 
bility. As the authors state, confirmation of their findings in other cohorts will be of substantial interest in the future.

In conclusion, the findings of this hypothesis-generating study, if replicated, could be of considerable importance, not only in elucidating the relationship between cytokine genes and CHD risk but also, more generally, in signposting the way towards identifying some of the 'missing heritability' that genetic epidemiologists are seeking in the postGWAS era.

\section{Abbreviations}

CHD: coronary heart disease; CRP: C-reactive protein; GWAS: genomewide association studies; SNP: single nucleotide polymorphism.

\section{Competing interests}

The author declares that he has no competing interests.

\section{Author Details}

BHF Professor of Cardiology, Institute of Human Genetics, Newcastle University, Newcastle, UK

Received: 11 December 2009 Accepted: 13 January 2010 Published: 13 January 2010

\section{References}

1. Brown BD, Nsengimana J, Barrett JH, Lawrence RA, Steiner L, Cheng S, Bishop DT, Samani NJ, Ball SG, Balmforth AJ, Hall AS: An evaluation of inflammatory gene polymorphisms in sibships discordant for premature coronary artery disease: The GRACE-IMMUNE study. BMC Med 2010, 8:5.

2. Buckley DI, Fu R, Freeman M, Rogers K, Helfand M: C-reactive protein as a risk factor for coronary heart disease: a systematic review and metaanalyses for the US Preventive Services Task Force. Ann Internal Med 2009, 151(7):483-495

3. Danesh J, Collins R, Appleby P, Peto R: Association of fibrinogen, Creactive protein, albumin, or leukocyte count with coronary heart disease: meta-analyses of prospective studies. JAMA 1998, 279(18):1477-1482.

4. Danesh J, Kaptoge S, Mann AG, Sarwar N, Wood A, Angleman SB, Wensley F, Higgins JP, Lennon L, Eiriksdottir G, Rumley A, Whincup PH, Lowe GD, Gudnason V: Long-term interleukin-6 levels and subsequent risk of coronary heart disease: two new prospective studies and a systematic review. PLoS Med 2008, 5(4):e78

5. Keavney B, Danesh J, Parish S, Palmer A, Clark S, Youngman L, Delepine M, Lathrop M, Peto R, Collins R: Fibrinogen and coronary heart disease: test of causality by 'Mendelian randomization'. Int J Epidemiol 2006, 35(4):935-943

6. Cook DG, Mendall MA, Whincup PH, Carey IM, Ballam L, Morris JE, Miller GJ, Strachan DP: C-reactive protein concentration in children: relationship to adiposity and other cardiovascular risk factors. Atherosclerosis 2000, 149(1):139-150.

7. Isasi CR, Deckelbaum RJ, Tracy RP, Starc TJ, Berglund L, Shea S: Physical fitness and C-reactive protein level in children and young adults: the Columbia University BioMarkers Study. Pediatrics 2003, 111(2):332-338.

8. Ford ES, Ajani UA, Mokdad AH: The metabolic syndrome and concentrations of C-reactive protein among US youth. Diabetes Care 2005, 28(4):878-881.

9. Elliott P, Chambers JC, Zhang W, Clarke R, Hopewell JC, Peden JF, Erdmann J, Braund P, Engert JC, Bennett D, Coin L, Ashby D, Tzoulaki I, Brown IJ, Mt-Isa S, MCCarthy MI, Peltonen L, Freimer NB, Farrall M, Ruokonen A, Hamsten A, Lim N, Froguel P, Waterworth DM, Vollenweider P, Waeber G, Jarvelin MR, Mooser V, Scott J, Hall AS, Schunkert H, Anand SS, Collins R, Samani NJ, Watkins H, Kooner JS: Genetic Loci associated with C-reactive protein levels and risk of coronary heart disease. JAMA 2009, 302(1):37-48.

10. Wellcome Trust Case Control Consortium: Genome-wide association study of 14,000 cases of seven common diseases and 3,000 shared controls. Nature 2007, 447(7145):661-678.
11. Samani NJ, Erdmann J, Hall AS, Hengstenberg C, Mangino M, Mayer B, Dixon RJ, Meitinger T, Braund P, Wichmann HE, Barrett JH, König IR, Stevens SE, Szymczak S, Tregouet DA, lles MM, Pahlke F, Pollard H, Lieb W, Cambien F, Fischer M, Ouwehand W, Blankenberg S, Balmforth AJ, Baessler A, Ball SG, Strom TM, Braenne I, Gieger C, Deloukas P, Tobin MD, Ziegler A, Thompson JR, Schunkert H, WTCCC and the Cardiogenics Consortium: Genomewide association analysis of coronary artery disease. New Eng J Med 2007, 357(5):443-453.

12. Helgadottir A, Thorleifsson G, Magnusson KP, Grétarsdottir S, Steinthorsdottir V, Manolescu A, Jones GT, Rinkel GJ, Blankensteijn JD, Ronkainen A, Jääskeläinen JE, Kyo Y, Lenk GM, Sakalihasan N, Kostulas K, Gottsäter A, Flex A, Stefansson H, Hansen T, Andersen G, Weinsheimer S, Borch-Johnsen K, Jorgensen T, Shah SH, Quyyumi AA, Granger CB, Reilly MP, Austin $\mathrm{H}$, Levey Al, Vaccarino V, et al.: The same sequence variant on 9p21 associates with myocardial infarction, abdominal aortic aneurysm and intracranial aneurysm. Nature Genetics 2008, 40(2):217-224

13. Helgadottir A, Thorleifsson G, Manolescu A, Gretarsdottir S, Blondal T, Jonasdottir A, Jonasdottir A, Sigurdsson A, Baker A, Palsson A, Masson G, Gudbjartsson DF, Magnusson KP, Andersen K, Levey Al, Backman VM, Matthiasdottir S, Jonsdottir T, Palsson S, Einarsdottir H, Gunnarsdottir S, Gylfason A, Vaccarino V, Hooper WC, Reilly MP, Granger CB, Austin H, Rader DJ, Shah SH, Quyyumi AA, Gulcher JR, Thorgeirsson G, Thorsteinsdottir U, Kong A, Stefansson K: A common variant on chromosome 9p21 affects the risk of myocardial infarction. Science (NY) 2007, 316(5830):1491-1493

14. McPherson R, Pertsemlidis A, Kavaslar N, Stewart A, Roberts R, Cox DR, Hinds DA, Pennacchio LA, Tybjaerg-Hansen A, Folsom AR, Boerwinkle E, Hobbs HH, Cohen JC: A common allele on chromosome 9 associated with coronary heart disease. Science (NY) 2007, 316(5830):1488-1491.

15. Erdmann J, Grosshennig A, Braund PS, König IR, Hengstenberg C, Hall AS, Linsel-Nitschke P, Kathiresan S, Wright B, Trégouët DA, Cambien F, Bruse P, Aherrahrou Z, Wagner AK, Stark K, Schwartz SM, Salomaa V, Elosua R, Melander O, Voight BF, O'Donnell CJ, Peltonen L, Siscovick DS, Altshuler D, Merlini PA, Peyvandi F, Bernardinelli L, Ardissino D, Schillert A, Blankenberg $S$, et al:: New susceptibility locus for coronary artery disease on chromosome 3q22.3. Nature Genetics 2009, 41(3):280-282.

16. Trégouët DA, König IR, Erdmann J, Munteanu A, Braund PS, Hall AS, Grosshennig A, Linsel-Nitschke P, Perret C, DeSuremain M, Meitinger T, Wright BJ, Preuss M, Balmforth AJ, Ball SG, Meisinger C, Germain C, Evans A, Arveiler D, Luc G, Ruidavets JB, Morrison C, Harst P van der, Schreiber S, Neureuther K, Schäfer A, Bugert P, El Mokhtari NE, Schrezenmeir J, Stark K, Rubin $D$, et al.: Genome-wide haplotype association study identifies the SLC22A3-LPAL2-LPA gene cluster as a risk locus for coronary artery disease. Nature Genetics 2009, 41(3):283-285

17. Myocardial Infarction Genetics Consortium, Kathiresan S, Voight BF, Purcell S, Musunuru K, Ardissino D, Mannucci PM, Anand S, Engert JC, Samani NJ, Schunkert H, Erdmann J, Reilly MP, Rader DJ, Morgan T, Spertus JA, Stoll M, Girelli D, McKeown PP, Patterson CC, Siscovick DS, O'Donnell CJ, Elosua R, Peltonen L, Salomaa V, Schwartz SM, Melander O, Altshuler D, Ardissino D, Merlini PA, et al: Genome-wide association of early-onset myocardial infarction with single nucleotide polymorphisms and copy number variants. Nature Genetics 2009. 41(3):334-341.

18. Keavney B, Parish S, Palmer A, Clark S, Youngman L, Danesh J, McKenzie C, Delépine M, Lathrop M, Peto R, Collins R, International Studies of Infarct Survival (ISIS) Collaborators: Large-scale evidence that the cardiotoxicity of smoking is not significantly modified by the apolipoprotein $\mathrm{E}$ epsilon2/epsilon3/epsilon4 genotype. Lancet 2003, 361(9355):396-398.

19. Sandhu MS, Waterworth DM, Debenham SL, Wheeler E, Papadakis K, Zhao JH, Song K, Yuan X, Johnson T, Ashford S, Inouye M, Luben R, Sims M, Hadley D, McArdle W, Barter P, Kesäniemi YA, Mahley RW, McPherson R, Grundy SM, Wellcome Trust Case Control Consortium, Bingham SA, Khaw KT, Loos RJ, Waeber G, Barroso I, Strachan DP, Deloukas P, Vollenweider P, Wareham NJ, Mooser V: LDL-cholesterol concentrations: a genomewide association study. Lancet 2008, 371(9611):483-491.

20. Aulchenko YS, Ripatti S, Lindqvist I, Boomsma D, Heid IM, Pramstaller PP, Penninx BW, Janssens AC, Wilson JF, Spector T, Martin NG, Pedersen NL, Kyvik KO, Kaprio J, Hofman A, Freimer NB, Jarvelin MR, Gyllensten U, 
Campbell H, Rudan I, Johansson A, Marroni F, Hayward C, Vitart V, Jonasson I, Pattaro C, Wright A, Hastie N, Pichler I, et al: Loci influencing lipid levels and coronary heart disease risk in 16 European population cohorts. Nature Genetics 2009, 41(1):47-55.

21. Kathiresan S, Willer CJ, Peloso GM, Demissie S, Musunuru K, Schadt EE, Kaplan L, Bennett D, Li Y, Tanaka T, Voight BF, Bonnycastle LL, Jackson AU, Crawford G, Surti A, Guiducci C, Burtt NP, Parish S, Clarke R, Zelenika D, Kubalanza KA, Morken MA, Scott LJ, Stringham HM, Galan P, Swift AJ, Kuusisto J, Bergman RN, Sundvall J, Laakso M, et al.: Common variants at 30 loci contribute to polygenic dyslipidemia. Nature Genetics 2009, 41(1):56-65.

22. Chasman DI, Paré G, Mora S, Hopewell JC, Peloso G, Clarke R, Cupples LA, Hamsten A, Kathiresan S, Mälarstig A, Ordovas JM, Ripatti S, Parker AN Miletich JP, Ridker PM: Forty-three loci associated with plasma lipoprotein size, concentration, and cholesterol content in genomewide analysis. PLoS Genetics 2009, 5(11):e 1000730.

\section{Pre-publication history}

The pre-publication history for this paper can be accessed here: http://www.biomedcentral.com/1741-7015/8/6/prepub

\section{doi: 10.1186/1741-7015-8-6}

Cite this article as: Keavney, The interleukin-1 cluster, dyslipidaemia and risk of myocardial infarction BMC Medicine 2010, 8:6 